\title{
Microbial transformation of anti-cancer steroid exemestane and cytotoxicity of its metabolites against cancer cell lines
}

\author{
Elias Baydoun ${ }^{1 *}$, Marium Bibi ${ }^{2}$, Muhammad Asif Iqbal ${ }^{2}$, Atia-tul Wahab ${ }^{3}$, Dina Farran ${ }^{1}$, Colon Smith ${ }^{1}$, \\ Samina A Sattar ${ }^{2}$, Atta-ur Rahman ${ }^{2,3}$ and M lqbal Choudhary ${ }^{2,3,4^{*}}$
}

\begin{abstract}
Background: Microbial transformation of steroids has been extensively used for the synthesis of steroidal drugs, that often yield novel analogues, not easy to obtain by chemical synthesis. We report here fungal transformation of a synthetic steroidal drug, exemestane, used for the treatment of breast cancer and function through inhibition of aromatase enzyme.

Results: Microbial transformation of anti-cancer steroid, exemestane (1), was investigated by using two filamentous fungi. Incubation of 1 with fungi Macrophomina phaseolina, and Fusarium lini afforded three new, 11a-hydroxy-6methylene-androsta-1, 4-diene-3,17-dione (2), 16ß, 17ß-dihydroxy-6-methylene-androsta-1, 4-diene-3-one (3), and 17ß-hydroxy-6-methylene-androsta-1, 4-diene-3, 16-dione (4), and one known metabolites, 17ß-hydroxy-6methylene-androsta-1, 4-diene-3-one (5). Their structures were deduced spectroscopically. Compared to 1 (steroidal aromatase inactivator), the transformed metabolites were also evaluated for cytotoxic activity by using a cell viability assay against cancer cell lines (HeLa and PC3). Metabolite 2 was found to be moderately active against both the cell lines.

Conclusions: Biotransformation of exemestane (1) provides an efficient method for the synthesis of new analogues of 1 . The metabolites were obtained as a result of reduction of double bond and hydroxylation. The transformed product 2 exhibited a moderate activity against cancer cell lines (HeLa and PC3). These transformed products can be studied for their potential as drug candidates.
\end{abstract}

Keywords: Steroid, Exemestane, Anti-cancer activity, Cancer cell lines (HeLa, PC3), Fusarium lini, Macrophomina phaseolina, Microbial transformation

\section{Background}

Microbial transformation of steroids has been extensively employed for the synthesis of steroidal drugs, both at laboratory and industrial levels [1-7]. In modern drug discovery process, generation of libraries of bioactive compounds with diverse structures plays an important role $[8]$.

Exemstane (trade name aromasin) is a steroidal irreversible aromatase inhibitor, used for the treatment of breast cancer. Breast cancers have estrogen receptors

\footnotetext{
* Correspondence: eliasbay1@yahoo.com; iqbal.choudhary@iccs.edu

${ }^{1}$ American University of Beirut, Beirut 1107 2020, Lebanon

${ }^{2} \mathrm{H}$. E. J. Research Institute of Chemistry, International Center for Chemical and Biological Sciences, University of Karachi, Karachi 75270, Pakistan

Full list of author information is available at the end of the article
}

(ER-positive) and their growth depends on aromatase activity. Therefore, inhibition of aromatase enzyme reduces the estrogen levels and thus slows the growth of breast cancer [9-12].

Interestingly exemestane not only increases the testosterone level and lowers estrogen, but it also increases the levels of insulin-like growth factor (IGF) [10]. The large reduction in estrogen levels combined with a rise in IGF, makes exemestane an effective breast cancer medication [13-15]. Based on the importance of exemestane in the treatment of breast cancer, a number of exemestane derivatives were previously synthesized involving modification of C-6 methylene and reduction

\section{(C) Chemistry Central}




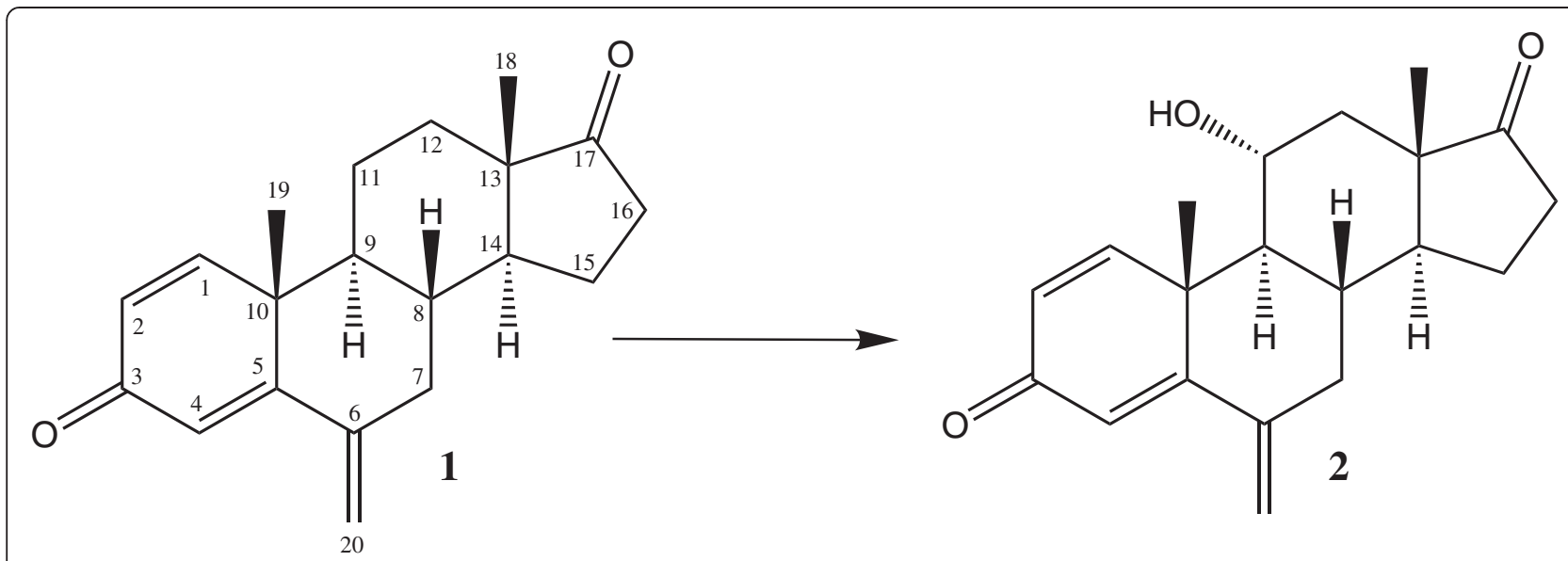

Figure 1 Biotransformation of exemestane (1) with Fusarium lini yielded metabolite 2.

of $\mathrm{C}-17$ keto group, and evaluated for their aromatase inhibitory potential [16-19].

During current study, we synthesized new analogues of 1 by biotransformation techniques. Screening experiments showed that Macrophomina phaseolina and
Fusarium lini were able to efficiently transform 1 into several metabolites. Subsequent large scale fermentations produced three new metabolites $\mathbf{2 - 4}$ along with a known metabolite 5. The structures of metabolites were unambiguously established through detailed spectral analysis.

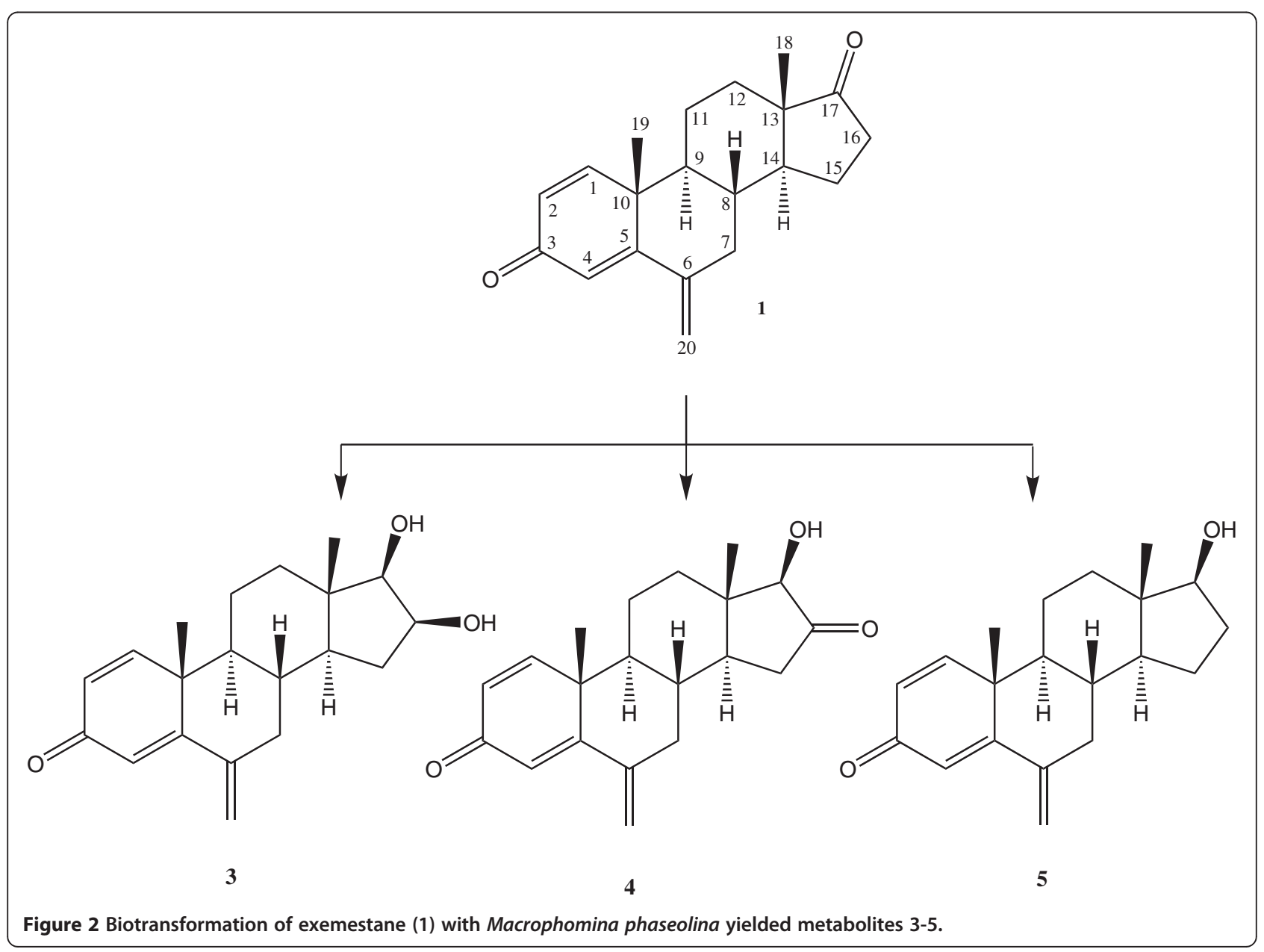


Table $1{ }^{1} \mathrm{H}$-NMR data of compounds 1-5 in ppm, $J$ in $\mathrm{Hz}$

\begin{tabular}{|c|c|c|c|c|c|}
\hline \multicolumn{6}{|c|}{ COMPOUNDS } \\
\hline Carbon & $1^{a}$ & $2^{a}$ & $3^{b}$ & $4^{b}$ & $5^{b}$ \\
\hline 1 & $7.21 \mathrm{~d}(10.0)$ & $7.21 \mathrm{~d}(10.5)$ & $7.31 \mathrm{~d}(10.2)$ & $7.34 \mathrm{~d}(10.5)$ & $7.31 \mathrm{~d}(10.2)$ \\
\hline 2 & $6.14 \mathrm{dd}(10.5,2.0)$ & $6.12 \mathrm{dd}(10.5,2.0)$ & $6.21 \mathrm{dd}(10.2,1.8)$ & $6.42, \mathrm{dd}(10.5,2.0)$ & $6.22 \mathrm{dd}(10.2,1.8)$ \\
\hline 3 & - & - & - & - & - \\
\hline 4 & $5.99, d(2.0)$ & $6.00 \mathrm{~d}(2.0)$ & $6.08 d(1.8)$ & $6.11 \mathrm{~d}(2.0)$ & $6.09 \mathrm{~d}(1.8)$ \\
\hline 5 & - & - & - & - & - \\
\hline 6 & - & - & - & - & - \\
\hline 7 & $2.69,1.97 \mathrm{~m}$ & $2.13,1.28 \mathrm{~m}$ & $2.56 \mathrm{~d}(9.0), 1.87 \mathrm{~m}$ & $2.57,1.96 \mathrm{~m}$ & $2.66,1.82 \mathrm{~m}$ \\
\hline 8 & $2.03 \mathrm{~m}$ & $1.98 \mathrm{~m}$ & $1.86 \mathrm{~m}$ & $1.98 \mathrm{~m}$ & $1.83 \mathrm{~m}$ \\
\hline 9 & $1.34 \mathrm{~m}$ & $1.62 \mathrm{~m}$ & $1.35 \mathrm{~m}$ & $1.48 \mathrm{~m}$ & $1.05 \mathrm{~m}$ \\
\hline 10 & - & - & - & - & - \\
\hline 11 & $1.92,1.76 \mathrm{~m}$ & $4.30 \mathrm{~m}$ & $1.91,1.31 \mathrm{~m}$ & $1.93,1.84 \mathrm{~m}$ & $1.75,1.83 \mathrm{~m}$ \\
\hline 12 & $1.78,1.28 \mathrm{~m}$ & $2.13,1.28 \mathrm{~m}$ & $1.90,1.16 \mathrm{~m}$ & $2.01,1.45 \mathrm{~m}$ & $1.13,1.92 \mathrm{~m}$ \\
\hline 13 & - & - & - & - & - \\
\hline 14 & $1.43 \mathrm{~m}$ & $1.37 \mathrm{~m}$ & $0.93 \mathrm{~m}$ & $1.63 \mathrm{~m}$ & $1.27 \mathrm{~m}$ \\
\hline 15 & $1.99,1.67 \mathrm{~m}$ & $1.93,1.80 \mathrm{~m}$ & $2.20,1.30 \mathrm{~m}$ & $2.29,1.95 \mathrm{~m}$ & $1.65,1.38 \mathrm{~m}$ \\
\hline 16 & $2.41,1.95 \mathrm{~m}$ & $2.66,1.95 \mathrm{~m}$ & $4.07 \mathrm{~m}$ & - & $2.00,1.51 \mathrm{~m}$ \\
\hline 17 & - & - & $3.30 \mathrm{~d}(7.5)$ & $3.77 \mathrm{~s}$ & 3.55 t (8.7) \\
\hline 18 & $0.92 \mathrm{~s}$ & $0.99 \mathrm{~s}$ & $0.99 \mathrm{~s}$ & $0.81 \mathrm{~s}$ & $0.81 \mathrm{~s}$ \\
\hline 19 & $1.19 \mathrm{~s}$ & $1.18 \mathrm{~s}$ & $1.18 \mathrm{~s}$ & $1.21 \mathrm{~s}$ & $1.17 \mathrm{~s}$ \\
\hline 20 & $5.03,5.01 \mathrm{~s}$ & $5.04,5.02 \mathrm{~s}$ & $5.02 \mathrm{t}(1.9)$ & $5.06,5.04 \mathrm{~s}$ & $4.99,5.01 \mathrm{~s}$ \\
\hline
\end{tabular}

$500 \mathrm{MHz}\left(\mathrm{CD}_{3}\right)_{2} \mathrm{CO}$

b $300 \mathrm{MHz} \mathrm{CD}$ OD.

The microbial transformed metabolites $\mathbf{2}$ and $\mathbf{4}$ of exemestane showed a moderate anti-cancer effect against PC3 and/or Hela cancer cell lines. This successful attempt to synthesize new derivatives of an anti-cancer steroid may lead to the discovery of new cancer therapeutic agents.

\section{Results and discussion}

Four microbial metabolites were generated by the selected fungal strains, i.e. Macrophomina phaseolina and Fusarium lini (Figures 1 and 2). M. phaseolina is previously reported to catalyze the introduction of double bond between $\mathrm{C}-1$ and $\mathrm{C}-2$, hydroxyl groups at $\mathrm{C}-6, \mathrm{C}-15, \mathrm{C}-16$ and $\mathrm{C}-17$, and carbonyl group at $\mathrm{C}-17$ of the steroidal skeleton $[1,20]$. F. lini is also reported to catalyze the oxidation at $\mathrm{C}-1, \mathrm{C}-2, \mathrm{C}-6$, and $\mathrm{C}-11$ of steroidal skeleton [21]. The chemical structures of the metabolites $\mathbf{2 - 4}$ are reported here for the first time along with their NMR data (Tables 1 and 2).

The anti-cancer effect of exemestane (1) [2] and its synthetic analogues on HeLa and PC3 were determined by using MTT assay. Results obtained from these assays are presented in Table 3.

The molecular formula $\mathrm{C}_{20} \mathrm{H}_{24} \mathrm{O}_{3}\left[M^{+}, m / z\right.$ 312] of metabolite 2 was deduced from the HREI-MS $\left(M^{+} \mathrm{m} / z\right.$
312.1705), suggested the addition of an oxygen in substrate 1 . The ${ }^{1} \mathrm{H}$-NMR spectral analysis of $\mathbf{2}$ (Table 1 ) displayed a downfield methine signal, as compared to the starting material exemestane (1), resonating at $\delta 4.30\left(\mathrm{~m}, W_{1 / 2}=15.6 \mathrm{~Hz}\right)$, while its respective carbon signal was at $\delta 71.5$ in ${ }^{13} \mathrm{C}$-NMR spectrum (Table 2). The HMBC spectrum (Figure 3 ) displayed long-range couplings of the hydroxyl-bearing methine proton $(\delta 4.30)$ with C-9 ( $\delta$ 48.6), C-10 ( $\delta$ 44.3), and C-13 ( $\delta$ 48.1), which suggested the position of the hydroxyl-bearing methine at $\mathrm{C}-11$. $\mathrm{H}-11$ also showed COSY cross peaks with $\mathrm{H}-9(\delta 1.62)$ and $\mathrm{H}_{2}-12(\delta 1.28,2.13)$. The stereochemical assignments were based on NOESY interactions (Figure 3) between H-11 ( $\delta 4.30), \mathrm{H}-8$ ( $\delta 1.98)$, and Me-19 ( $\delta$ 1.18). $\mathrm{H}$-11 was thus deduced as $\beta$-oriented. Metabolite 2 was finally identified as $11 \alpha$-hydroxy-6-methyleneandrosta-1,4-diene-3,17-dione.

Molecular composition of metabolite 3 was deduced to be $\mathrm{C}_{20} \mathrm{H}_{26} \mathrm{O}_{3}$ from the HREI-MS analysis $\left(M^{+}=\mathrm{m} / \mathrm{z}\right.$ 314.1933, calcd 314.1882). The ${ }^{1} \mathrm{H}-\mathrm{NMR}$ spectra $\mu \mathrm{m}$ (Table 1) of metabolite 3 showed two hydroxyl-bearing methine proton peaks at $\delta 3.30\left(\mathrm{~d}, J_{17,16}=7.5 \mathrm{~Hz}, \mathrm{H}-17\right)$ and $4.07\left(\mathrm{~m}, W_{1 / 2}=20.0 \mathrm{~Hz}\right)$. The ${ }^{13} \mathrm{C}$-NMR spectrum of 3 lacks signal for $\mathrm{C}-17$ carbonyl, whereas new methine 
Table $2{ }^{13} \mathrm{C}$-NMR data of compounds $1-5$ in ppm

\begin{tabular}{|c|c|c|c|c|c|}
\hline \multicolumn{6}{|c|}{ COMPOUNDS } \\
\hline Carbon & $1^{a}$ & $2^{b}$ & $3^{c}$ & $4^{d}$ & $5^{d}$ \\
\hline 1 & 155.0 & 154.9 & 158.1 & 157.6 & 158.2 \\
\hline 2 & 128.0 & 128.0 & 127.8 & 127.9 & 127.7 \\
\hline 3 & 185.8 & 185.8 & 188.7 & 188.6 & 188.7 \\
\hline 4 & 122.9 & 122.9 & 122.7 & 122.8 & 122.7 \\
\hline 5 & 167.9 & 167.9 & 171.6 & 171.2 & 171.7 \\
\hline 6 & 147.1 & 147.0 & 147.7 & 147.3 & 147.8 \\
\hline 7 & 39.87 & 32.1 & 41.4 & 41.2 & 41.3 \\
\hline 8 & 36.0 & 39.6 & 36.6 & 35.9 & 37.2 \\
\hline 9 & 50.9 & 48.6 & 51.9 & 51.4 & 51.7 \\
\hline 10 & 44.3 & 44.3 & 45.6 & 45.5 & 45.6 \\
\hline 11 & 22.63 & 71.5 & 23.0 & 23.2 & 23.6 \\
\hline 12 & 32.0 & 32.0 & 38.1 & 36.6 & 37.5 \\
\hline 13 & 48.1 & 48.1 & 43.7 & 43.5 & 44.2 \\
\hline 14 & 51.3 & 50.8 & 48.2 & 45.4 & 51.8 \\
\hline 15 & 22.3 & 22.3 & 35.9 & 36.6 & 24.3 \\
\hline 16 & 35.8 & 39.7 & 70.6 & 217.7 & 30.5 \\
\hline 17 & 218.8 & 218.0 & 81.7 & 86.8 & 82.1 \\
\hline 18 & 13.9 & 14.5 & 12.5 & 11.9 & 11.6 \\
\hline 19 & 20.1 & 20.1 & 20.1 & 20.1 & 20.1 \\
\hline 20 & 112.2 & 112.2 & 112.6 & 112.9 & 112.4 \\
\hline
\end{tabular}

carbon at $\delta 81.7$ suggested the reduction of $\mathrm{C}-17$ ketone into $\mathrm{C}-17 \mathrm{OH}$. The proton geminal to the $-\mathrm{OH}$ group ( $\delta$ 4.07) was correlated with C-13 ( $\delta$ 43.7), C-14 ( $\delta$ 48.2) and $\mathrm{C}-17(\delta$ 81.7) in the HMBC spectrum. The methine C-17 $(\delta$ 81.7) showed HMBC correlations with $\mathrm{H}-14$ $(\delta 0.93, \mathrm{~m})$ and $\mathrm{H}-18(\delta 0.99, \mathrm{~s})$. Based on the above observations, the hydroxyl-bearing methine carbon was identified as $\mathrm{C}-16$. The $\mathrm{H}-16$ ( $\delta 4.07)$ showed NOESY cross peaks with $\mathrm{H}-14$ ( $\delta 0.93)$, but no interaction with $\mathrm{H}-18$ ( $\delta$ 0.99) (Figure 4). Therefore the $\mathrm{C}-16$ proton was assigned to be $\alpha$-oriented. The metabolite 3 was thus identified as $16 \beta, 17 \beta$-dihydroxy-6-methylene-androsta-1, 4-diene-3-one.

Table 3 In vitro cytotoxicity of compounds 1-5

\begin{tabular}{ccc}
\hline Compound Codes & $\begin{array}{c}\text { HeLa (Cervical cancer) } \\
\left(\text { IC }_{\mathbf{5 0}} \pm \text { S.D. }\right) \boldsymbol{\mu M}\end{array}$ & $\begin{array}{c}\text { PC-3 (Prostate cancer) } \\
\left(\text { IC }_{\mathbf{5 0}} \pm \text { S.D. }\right) \boldsymbol{\mu M}\end{array}$ \\
\hline $\mathbf{1}$ & $>50$ & $>50$ \\
$\mathbf{2}$ & $16.83 \pm 0.96$ & $24.87 \pm 0.72$ \\
$\mathbf{3}$ & $>50$ & $>50$ \\
$\mathbf{4}$ & $37.20 \pm 0.88$ & $>50$ \\
$\mathbf{5}$ & $>50$ & $>50$ \\
Doxorubicin & $\mathbf{3 . 1 0} \pm \mathbf{0 . 2 0}$ & $\mathbf{0 . 9 1} \pm \mathbf{0 . 1 2}$ \\
\hline
\end{tabular}

Molecular formula $\mathrm{C}_{20} \mathrm{H}_{24} \mathrm{O}_{3}\left(M^{+} \mathrm{m} / z\right.$ 312.1725, calcd 312.1720) was deduced from the HREI-MS of metabolite 4. A distinct downfield methine proton signal appeared at $\delta 3.77$ (br. s, $W_{1 / 2}=9.3 \mathrm{~Hz}$ ) in the ${ }^{1} \mathrm{H}$-NMR spectrum of 4. The ${ }^{13} \mathrm{C}$-NMR spectrum showed a saturated ketone carbon signal at $\delta$ 217.7. The rest of the spectrum was distinctly similar to metabolite 2 . The deshielded methine proton was $\mathrm{HMBC}$ correlated with this ketonic carbon, while its corresponding methine carbon at $\delta 86.8$ showed the HMBC correlations with $\mathrm{H}_{2}-15(\delta 1.95,2.29)$, and $\mathrm{CH}_{3}-18$ ( $\delta$ 0.81). These interactions, along with appearance of a downfield proton $(\delta 3.77)$, indicated that the ketone at $\mathrm{C}-17$ has been reduced into an $-\mathrm{OH}$. Geminal $\mathrm{H}-17$ ( $\delta$ 3.77) showed NOESY correlations with $\mathrm{H}-14$ $(\delta 1.63)$, indicating it to be axially $(\alpha-)$ oriented. The saturated ketone carbon $(\delta 217.7)$ was place at $C-16$, based on the above mentioned HMBC correlations (Figure 5). The structure of metabolite 4 was finally identified as $17 \beta-$ hydroxy-6-methylene-androsta-1, 4-diene-3, 16-dione.

Metabolite 5 has a molecular composition $\mathrm{C}_{20} \mathrm{H}_{26} \mathrm{O}_{2}$ (HREI-MS, $M^{+} \mathrm{m} / \mathrm{z}$ 298.1730, calcd 298.1733). Based on ${ }^{1} \mathrm{H}$ - and ${ }^{13} \mathrm{C}-\mathrm{NMR}$ spectral data (Tables 1 and 2), compound 5 was identified as $17 \beta$-hydroxy- 6 -methyleneandrosta-1, 4-diene-3-one. It has previously been reported as an in-vitro cytochrome $\mathrm{P}_{450}$-mediated transformed product of exemestane [22].

The cytotoxic effect of the compounds 1-5 against two tumor cell lines, PC-3 (prostate cancer cell) and Hela (cervical cancer cell), was evaluated (Table 3) using the MTT assay. Compound 2 showed a moderate cytotoxicity against both the cancer cell line with $\mathrm{IC}_{50}=16.83 \pm 0.96$ and $24.87 \pm 0.72 \mu \mathrm{M}$, respectively, as compared to the standard drug, doxorubicin. Compound 4 exhibited a moderate activity against HeLa cell line.

\section{Conclusion}

In conclusion, the biotransformation of exemestane (1) with $F$. lini and M. phaseolina were investigated for the first time which provided an efficient route towards the synthesis of several new metabolites 2-5. Metabolite 2 was found to be moderately active against both cancer cell lines (HeLa and PC3). The work presented here can be helpful for the study of in vivo metabolism of exemestane (1), as well as for the discovery of new anticancer drugs

\section{Experimental}

\section{Substrate and chemicals}

Exemestane (1) was purchased from local market as drug (Pfizer Canada Inc., Brand name Aromasin), extracted and further purified by flash chromatography. Thin layer chromatography (TLC) was carried out on silica gel precoated plates $\left(\mathrm{PF}_{254}\right.$; Merck). Column chromatography (CC) was performed by using silica gel (E. Merck, Germany). Optical rotations were measured in methanol with a 


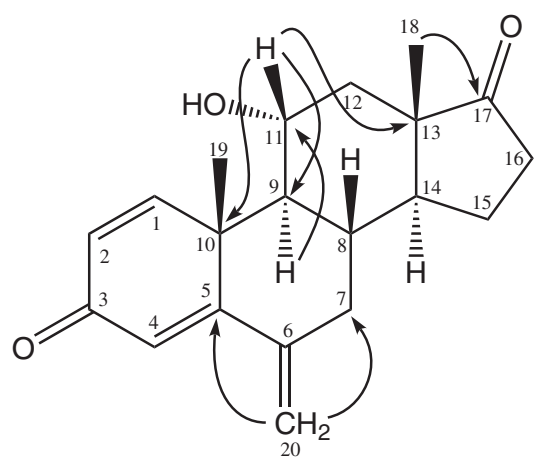

a

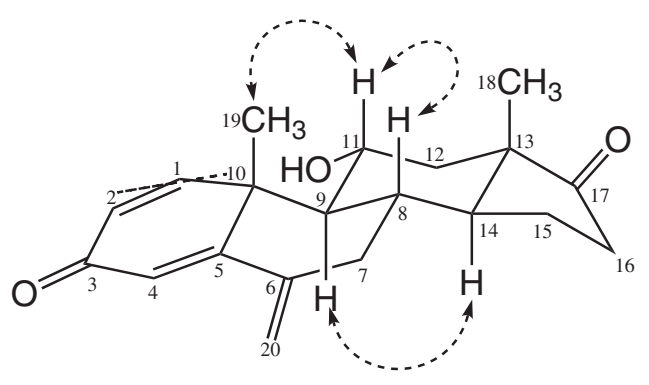

b

Figure 3 Important HMBC (a) and NOESY (b) correlations in metabolite 2.

JASCO P-2000 polarimeter. ${ }^{1} \mathrm{H}$ - and ${ }^{13} \mathrm{C}-\mathrm{NMR}$ spectra were recorded in $\left(\mathrm{CD}_{3}\right)_{2} \mathrm{CO}$ and $\mathrm{CD}_{3} \mathrm{OD}$ on Bruker Avance spectrometers. The chemical shifts ( $\delta$ values) are presented in $\mathrm{ppm}$ and the coupling constants $(J)$ are in Hz. For 1D- and 2D-NMR experiments, standard Bruker pulse sequences were used. UV Spectra (in $\mathrm{nm}$ ) were recorded in methanol with a Hitachi U-3200 spectrophotometer. Infrared (IR) spectra (in $\mathrm{cm}^{-1}$ ) were recorded with an FT-IR-8900 spectrophotometer. JEOL (Japan) JMS-600H mass spectrometer was used for recording of EI-MS and high-resolution mass spectra (HREI-MS) in $m / z$ (rel. \%).

The anticancer activity of compounds 2-5 was evaluated in 96-well flat-bottomed micro-titer plates [Iwaki, Japan] by using the standard dye MTT (3-[4, 5dimethylthiazole-2-yl]-2, 5-diphenyl-tetrazolium bromide) [Sigma-Aldrich Chemicals, St. Louis, USA] through colorimetric analysis. For this purpose, the cells were cultured in Minimum Essential Medium (MEM), supplemented with $10 \%$ Fetal Calf Serum (FCS), $1 \mathrm{mmol} /$ l sodium pyruvate, $1 \%(\mathrm{v} / \mathrm{v})$ antibiotic / antimycotic and passaged weekly, using 0.25\% trypsin / EDTA [SigmaAldrich Chemicals, St. Louis, USA] in tissue culture flasks T-75 [Iwaki, Japan]. Absorbance was taken at 540 $\mathrm{nm}$ wavelength by using microplate reader (Spectra Max plus, Molecular Devices, USA) using software SoftMax Pro 340 [Molecular Devices, CA, USA]. Dimethyl sulfoxide (DMSO) and doxorubicin (standard inhibitor) were purchased from Sigma-Aldrich Chemicals, [St. Louis, USA].

\section{Microorganisms and culture medium}

The fungi were purchased from the Northern Regional Research Laboratories (NRRL), or obtained as gift from the Karachi University Culture Collection (KUCC).

Fusarium lini (NRRL 2204), and Macrophomina phaseolina (KUCC 730) were grown in a culture medium prepared by mixing glucose $(40.0 \mathrm{~g})$, glycerol $(40.0 \mathrm{~mL})$, peptone $(20.0 \mathrm{~g})$, yeast extract $(20.0 \mathrm{~g})$, $\mathrm{KH}_{2} \mathrm{PO}_{4}(20.0 \mathrm{~g})$, and $\mathrm{NaCl}(20.0 \mathrm{~g})$ in distilled $\mathrm{H}_{2} \mathrm{O}(4.0 \mathrm{~L})$.

\section{Cell lines}

PC3 (prostate cancer) and HeLa (cervical cancer) cell lines were purchased from the American Type Culture Collection (ATCC) for anticancer activity.

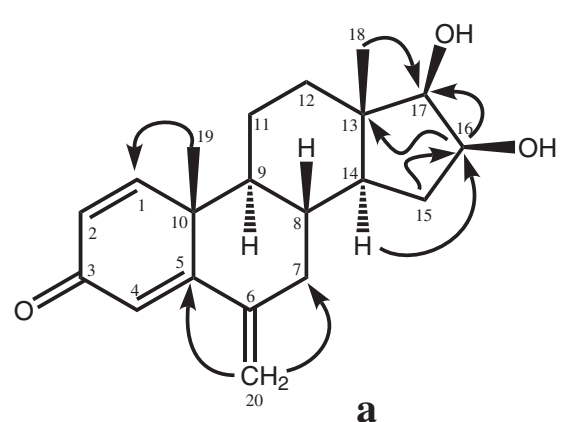

a

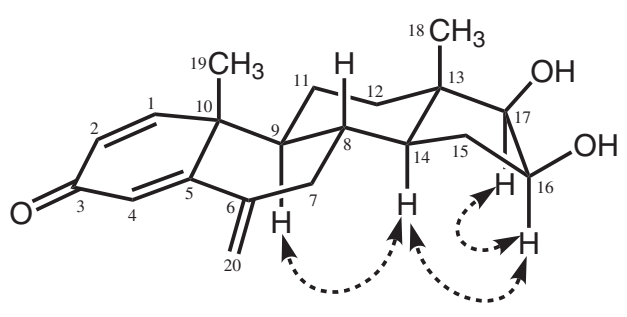

b

Figure 4 Important HMBC (a) and NOESY (b) correlations in metabolite 3. 

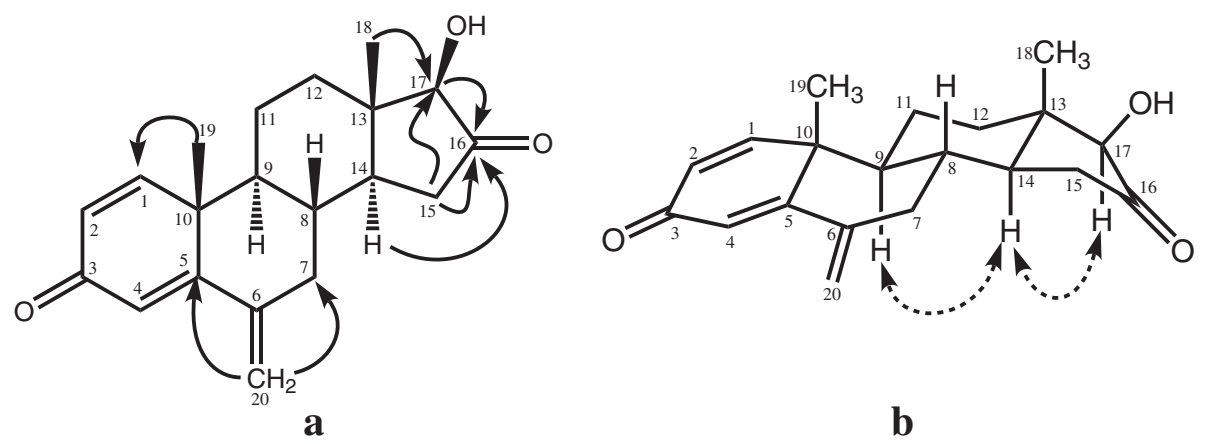

b

Figure 5 Important HMBC (a) and NOESY (b) correlations in metabolite 4.

\section{General Fermentation and Extraction Conditions}

4 Liters fungal media was prepared and distributed into 40 conical flasks (100 $\mathrm{mL}$ in each flask). All flasks were then autoclaved at $121^{\circ} \mathrm{C}$. The fungal cultures were then inoculated into each flask containing media and incubated at room temperature on shaker for three days. Compound $\mathbf{1}$ was dissolved in $40 \mathrm{~mL}$ methanol and distributed equally to all 40 flasks. All experimental flasks were then kept for fermentation. Two control experiments, i.e. media + compound $\mathbf{1}$ and media + fungus were also conducted. The transformation was then checked on TLC. After the detection of transformation on TLC, fungal culture from all 40 flasks was filtered and extracted with $\mathrm{CH}_{2} \mathrm{Cl}_{2}(12 \mathrm{~L})$ by using liquid-liquid chromatography. The dichloromethane layer was evaporated in vaccue. The obtained gum was analyzed by thin-layer chromatography.

\section{Fermentation and Purification of Exemestane (1) with Fusarium lini}

Exemestane $(1 ; 1.0 \mathrm{~g})$ was dissolved in $40 \mathrm{~mL}$ methanol, and incubated with culture of F. Lini. The obtained gum (2.3 g) was fractionated (ARC 1-3) by using silica gel column chromatography. The mobile phase was composed of petroleum ether and acetone with a gradient of $10 \%$. Fraction ARC-2 yielded metabolite 2 (4 mg, pet. ether: acetone $=8: 2$ ) after elution through silica gel column.

11a-Hydroxy-6-methylene-androsta-1,4-diene-3,17dione (2) Amorphous material; $[\alpha]_{\mathrm{D}}^{25}:+81.4(c=0.096$, $\mathrm{MeOH}) ; \quad I R \quad(\mathrm{KBr}): v_{\max } 3408,1657 \mathrm{~cm}^{-1}$; UV $(\mathrm{MeOH}): \lambda_{\max } \mathrm{nm}(\log \varepsilon) 247(3.78) ;{ }^{1} \mathrm{H}-$ and ${ }^{13} \mathrm{C}-$ NMR: see Tables 1 and 2 (Additional file 1).

Fermentation and Purification of Exemestane (1) with Macrophomina phaseolina Incubation of 1 (1.0 g / $40 \mathrm{~mL}$ methanol) with 3 days old culture of $M$. phaseolina in 40 flasks for 12 days produced the metabolites 3 (10 $\mathrm{mg}), 4$ (5 mg) and 5 (6 mg).
$16 \beta, 17 \beta$-Dihydroxy-6-methylene-androsta-1,4-diene3-one (3) Amorphous material; $[\alpha]^{25}$ : +181.6 ( $c=$ 0.032, MeOH); IR (KBr): $v_{\max } 3388,1658 \mathrm{~cm}^{-1}$; UV $(\mathrm{MeOH}): \lambda_{\max } \mathrm{nm}(\log \varepsilon) 249$ (4.03); ${ }^{1} \mathrm{H}-$ and ${ }^{13} \mathrm{C}-$ NMR: see Tables 1, and 2 (Additional file 2).

17ß-Hydroxy-6-methylene-androsta-1,4-diene-3,16-

dione (4) Amorphous material; $[\alpha]_{\mathrm{D}}^{25}$ : $-56.0(c=0.043$, $\mathrm{MeOH}) ; \mathrm{IR}(\mathrm{KBr}): v_{\max } 3411,1749,1658 \mathrm{~cm}^{-1}$; UV (MeOH): $\lambda_{\max } \mathrm{nm}(\log \varepsilon) 247(4.04) ;{ }^{1} \mathrm{H}$ - and ${ }^{13} \mathrm{C}-\mathrm{NMR}$ : see Tables 1 and 2 (Additional file 3).

\section{7ß-Hydroxy-6-methylene-androsta-1,4-diene-3-one}

(5) Amorphous material; $[\alpha]_{\mathrm{D}}^{25}$ : +174.5 ( $c=0.046$, $\mathrm{MeOH})$; IR (KBr): $v_{\max } 3421,1657, \mathrm{~cm}^{-1}$; UV (MeOH): $\lambda_{\max } \mathrm{nm}(\log \varepsilon) 248(4.24) ;{ }^{1} \mathrm{H}$ - and ${ }^{13} \mathrm{C}-\mathrm{NMR}$ : see Tables 1 and 2 (Additional file 4).

\section{Cell Viability Assay}

The cytotoxicity of metabolites 1-5 were determined by using MTT-based colorimetric assay in 96-well plate [23]. Both cell lines (PC-3 and HeLa) were cultured in DMEM and MEM media, respectively, in $25 \mathrm{~cm}^{3}$ tissue culture flasks. The media were supplemented with FBS (5\%), pencillin $(100 \mathrm{IU} / \mathrm{mL})$ and streptomycin $(100 \mathrm{mg} / \mathrm{mL})$. The flasks were then incubated at $37^{\circ} \mathrm{C}$ in an incubator containing $5 \% \mathrm{CO}_{2}$. The flask (80\% confluence) was processed for MTT-based cytotoxicity assay. The percent viability of the cells was monitored by trypan blue dye. The cells with clear cytoplasm were considered viable. For the assay, the cells $\left(1 \times 10^{5}\right)$ were loaded onto 96-well tissue culture treated plate. The plate was incubated for 24 hours at $37^{\circ} \mathrm{C}$. After incubation, the cells were treated with different concentrations (1.56-50 $\mu \mathrm{M}$ dissolved in DMSO) of compounds 1-5 and kept in an incubator for 48 hours at $37^{\circ} \mathrm{C}$. At the end of the incubation, the MTT dye (50 $\mu \mathrm{L}, 2 \mathrm{mg} / \mathrm{mL}$ ) was added to each well and the plate was incubated for 4 hours at $37^{\circ} \mathrm{C}$ in an incubator. Following incubation, the insoluble formazan crystals were dissolved by adding DMSO $(100 \mu \mathrm{L})$. 
The following formula was used to analyze the cytotoxic effects of the compounds.

$$
\begin{gathered}
\% \text { Inhibition }=100- \\
- \text { Absorbance of blank }) / \\
\\
\quad \text { Absorbance of control } \\
- \text { Absorbance of blank }) \times 100]
\end{gathered}
$$

\section{Additional files}

Additional file 1: Spectroscopic data of metabolite 2. Include spectra of El-MS, UV, IR, ${ }^{1} \mathrm{H}-\mathrm{NMR},{ }^{13} \mathrm{C}$-NMR (BB, DEPT-135 ${ }^{\circ}$, DEPT- $90^{\circ}$ ), HMQC, $\mathrm{HMBC}, \mathrm{COSY}-45^{\circ}$, NOESY experiments.

Additional file 2: Spectroscopic data of metabolite 3. Include spectra

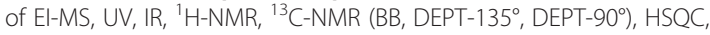
HMBC, COSY- $45^{\circ}$, NOESY experiments.

Additional file 3: Spectroscopic data of metabolite 4. Include spectra of El-MS, UV, IR, ${ }^{1} \mathrm{H}-\mathrm{NMR}$, ${ }^{13} \mathrm{C}-\mathrm{NMR}$ (BB, DEPT- $135^{\circ}$, DEPT-90), HMQC, HMBC, COSY- $45^{\circ}$, NOESY, experiments.

Additional file 4: Spectroscopic data of metabolite 5. Include spectra of El-MS, UV, IR, ${ }^{1} \mathrm{H}-\mathrm{NM}$, ${ }^{13} \mathrm{C}-\mathrm{NMR}$ (BB, DEPT-135 $5^{\circ}$, DEPT- $90^{\circ}$ ), HSQC, $\mathrm{HMBC}, \mathrm{COSY}-45^{\circ}$, NOESY experiments.

\section{Competing interests}

The authors declare that they have no competing interests.

\section{Authors' contributions}

$E B, M I C, A R, D F$, and CM participated in experimental strategy design, supervision and manuscript writing. MB and MAI carried out the experiments. AW performed NMR experiments, while SAS carried out the biological screenings. All authors read and approved the final manuscript.

\section{Acknowledgements}

We would like to acknowledge the Lebanese CNRS (Lebanese Council for Scientific Research) for a research grant.

\section{Author details}

${ }^{1}$ American University of Beirut, Beirut 1107 2020, Lebanon. ${ }^{2}$ H. E. J. Research Institute of Chemistry, International Center for Chemical and Biological Sciences, University of Karachi, Karachi 75270, Pakistan. ${ }^{3}$ Dr. Panjwani Center for Molecular Medicine and Drug Research, International Center for Chemical and Biological Sciences, University of Karachi, Karachi 75270, Pakistan. ${ }^{4}$ Department of Biochemistry, Faculty of Science, King Abdulaziz University, Jeddah 21412, Saudi Arabia.

Received: 22 January 2013 Accepted: 12 March 2013

Published: 27 March 2013

\section{References}

1. Choudhary MI, Zafar S, Khan NT, Ahmad S, Noreen S, Marasini BP, Al-Khedhairy AA: Atta-ur-Rahman: Biotransformation of dehydroepiandrosterone with Macrophomina phaseolina and $\beta$-glucuronidase inhibitory activity of transformed products. J Enzyme Inhib Med Chem 2012, 27:348-355.

2. Choudhary MI, Erum S, Atif M, Malik R, Khan NT, Atta-ur-Rahman: Biotransformation of (20S)-20-hydroxymethylpregna-1,4-dien-3-one by four filamentous fungi. Steroids 2011, 76:1288-1296.

3. Choudhary MI, Shah SAA, Atta-ur-Rahman, Khan SN, Khan MTH: aGlucosidase and tyrosinase inhibitors from fungal hydroxylation of tibolone and hydroxytibolones. Steroids 2010, 75:956-966.

4. Al-Aboudi A, Mohammad MY, Haddad S, Al-Far R, Choudhary Ml, Attaur-Rahman: Biotransformation of methyl cholate by Aspergillus niger. Steroids 2009, 74:483-486.
5. Choudhary MI, Mohammad MY, Musharraf SG, Parvez M, Al-Aboudi A, Atta-ur-Rahman: New oxandrolone derivatives by biotransformation using Rhizopus stolonifer. Steroids 2009, 74:1040-1044.

6. Choudhary MI, Khan NT, Musharraf SG, Anjum S, Atta-ur-Rahman: Biotransformation of adrenosterone by filamentous fungus, Cunninghamella elegans. Steroids 2007, 72:923-929.

7. Devkota KP, Choudhary MI, Nawaz SA, Lannang AM, Lenta BN, Fokou PA, Sewald N: Microbial transformation of the steroidal alkaloid dictyophlebine by Rhizopus stolonifer. Chem Pharm Bull 2007, 55:682-684.

8. Tong $W Y$, Dong $X$ : Microbial biotransformation: Recent development on steroid drugs. Recent Pat Biotechnol 2009, 3(2):141-153.

9. Henry NL, Azzouz F, Desta Z, Li L, Nguyen AT, Lemler S, Hayden J, Tarpinian K, Yakim E, Flockhart DA, Stearns V, Hayes DF, Storniolo AM: Predictors of aromatase inhibitor discontinuation as a result of treatment-Emergent symptoms in early-stage breast cancer. J Clin Oncol 2012, 30(9):936-942.

10. Mrozek E, Layman R, Ramaswamy B, Schaaf L, Li X, Ottman S, Shapiro CL: Phase II trial of exemestane in combination with fulvestrant in postmenopausal women with advanced, Hormone-Responsive Breast Cancer. Clin Breast Cancer 2012, 12(2):151-156.

11. Debled M, Le Loarer F, Callonnec F, Soubeyran I, Cambon-Michot C, Dujardin F, Italiano A: Complete response to exemestane in a patient with a desmoid tumor. Futur Oncol 2012, 8(4):483-486.

12. Hille U, Soergel P, Laenger F, Schippert C, Makowski L, Hillemanns P: Aromatase inhibitors as solely treatment in postmenopausal breast cancer patients. The Breast Journal 2012, 18(2):145-150.

13. Long B, Groothuis PG, Hicklin D: IGF1R Inhibitor based treatment of prostrate cancer.. International application number: PCT/US2010/055608 Publication number: WO/2011/05706, Filing date: Nov 05, 2010.

14. Van-Gool SA, Wit JM, De-Schutter T, De-Clerck N, Postnov AA, Hovinga SK, Van-Doorn J, Veiga SJ, Garcia-Segura LM, Karperien M: Marginal growth increase, altered bone quality and polycystic ovaries in female prepubertal rats after treatment with the aromatase inhibitor exemestane. Horm Res Paediatr 2010, 73(1):49-60.

15. Yamashita H, Takahashi S, Ito Y, Yamashita T, Ando Y, Toyama T, Sugiura $H$ Yoshimoto N, Kobayashi S, Fujii Y, Hirotaka I: Predictors of response to exemestane as primary endocrine therapy in estrogen receptor-positive breast cancer. Cancer Sci 2009, 100(11):2028-2033.

16. Pariza RJ, Yarger JG: (S)-6-Methyloxaalkyl exemestane compounds and related methods of use. 2010. US patent application number: 11/541,987 Publication number: US 2007/0088013 A1 Filing date: Oct 2, 2006 Issued patent: US7846918 (Issue date Dec 7, 2010).

17. Ariazi EA, Leitão A, Oprea TI, Chen B, Louis T, Bertucci AM, Sharma CGN, Gill SD, Kim HR, Shupp HA, Pyle JR, Madrack A, Donato AL, Cheng D, Paige JR, Jordan VC: Exemestane's 17-hydroxylated metabolite exerts biological effects as an androgen. Mol Cancer Ther 2007, 6(11):2817-2827.

18. Buzzetti F, Di Salle E, Longo A, Briatico G: Synthesis and aromatase inhibition by potential metabolites of exemestane (6-methylenandrosta1,4-diene-3,17-dione). Steroids 1993, 58(11):527-532.

19. Gorlitzer K, Bonnekessel C, Jones PG, Palusczak A, Hartmann RW: Exemestan-derivate - Synthese und prüfung auf aromatase-hemmung. Die Pharmazie 2006, 61:575-581.

20. Zafar S, Bibi M, Yousuf S, Choudhary Ml: New metabolites from fungal biotransformation of an oral contraceptive agent: Methyloestrenolone. Steroids 2013, 78(4):418-425.

21. Al-Maruf MA, Khan NT, Sakil MAA, Choudhary MI, Ali MU, Islam MA: Biotransformations of 11-ketoprogesterone by filamentous fungus, Fusarium lini. J Sci Res 2011, 3(2):347-356.

22. Kamdem LK, Flockhart DA, Desta Z: In Vitro cytochrome P450-mediated metabolism of exemestane. Drug Metab Disposition 2011, 39(1):98-105.

23. Mosmann T: Rapid colorimetric assay for cellular growth and survival: Application to proliferation and cytotoxicity assays. I Immunol Methods 1983, 65:55-63.

doi:10.1186/1752-153X-7-57

Cite this article as: Baydoun et al:: Microbial transformation of anticancer steroid exemestane and cytotoxicity of its metabolites against cancer cell lines. Chemistry Central Journal 2013 7:57. 